\title{
MAP7 promotes migration and invasion and progression of human cervical cancer through modulating the autophagy
}

\author{
Li Zhang $^{1 \dagger}$, Xudong Liu ${ }^{2 \dagger}$, Lina Song ${ }^{1}$, Hui Zhai $^{{ }^{*}}$ and Chaohua Chang ${ }^{3^{*}}$ (1)
}

\begin{abstract}
Background: Microtubule-associated proteins 7(MAP7) was reported to be engaged into the function of neuronal function. The function of MAP7 in human cervical cancer (CC) was unknown. We aimed to uncover the function and mechanism of MAP7 on CC.

Methods: We applied qRT-PCR, western blot and immunochemistry to detect the expression difference between normal tissue and CC. In vitro, we establish MAP7 stable knocking down and overexpression cell lines and investigated the function and underlying mechanism of MAP7 in CC.

Results: Both mRNA and protein of MAP7 were upregulated in CC compared with the normal tissue. MAP7 was correlated with the clinical stage and tumor size and lymph node metastasis. MAP7 promotes the invasion and migration of CC cell lines. We next detected EMT pathway and autophagy associated pathway. MAP7 promotes the EMT through modulating the autophagy.
\end{abstract}

Conclusion: Taken above, our results showed that MAP7 promotes the migration and invasion and EMT through modulating the autophagy.

Keywords: Cervical cancer, MAP7, Migration and invasion, Epithelial-mesenchymal transition

\section{Background}

Cervical cancer (CC) is the second most common gynecological carcinoma worldwide [1]. Through a lot of advancements in radiotherapy and immunotherapy was applied. Many patients with late stage of CC still suffers from recurrence and metastasis [2, 3]. However, more biomarkers predicting the prognosis and therapy targets were still needed.

\footnotetext{
*Correspondence: zhaisuhang@163.com; physiciana@sina.com

${ }^{\dagger}$ Li Zhang and Xudong Liu contributed equally to this article

${ }^{1}$ Department of Gynaecology and Obstetrics, Jinan Women and Children Health Hospital, No. 2 Jianguo Xiaojing 3rd Road Center Area, Jinan,

Shandong 250001, China

${ }^{3}$ Department of Anethesia, Jinan Women and Children Health Hospital,

No. 2 Jianguo Xiaojing 3rd Road Center Area, Jinan, Shandong 250001, China

Full list of author information is available at the end of the article
}

Microtubule was responsible for vital cellular processes such as cell division and differentiation $[4,5]$. Microtubules are continue remodeled through alternating growth and shrinkage of their extremities, known as dynamic instability. Microtubule associated protein 7 (MAP7) was crucial in the regulating of microtubule bundling and dynamics. MAP7 was reported to be engaged into the function of neuron cell [6]. MAP7 was reported to be upregulated and correlated with the prognosis of cancers $[7,8]$. The function and mechanism of MAP7 in CC was still unknow.

We applied qRT-PCR, Western blot and immunochemistry to detect the expression difference between normal tissue and CC after examining the function of MAP7 on $\mathrm{CC}$ cell lines. We found that MAP7 promotes the EMT of $\mathrm{CC}$ cell line through modulating the autophagy.

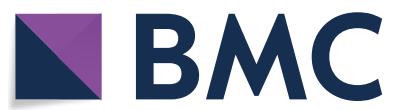

(c) The Author(s) 2020. This article is licensed under a Creative Commons Attribution 4.0 International License, which permits use, sharing, adaptation, distribution and reproduction in any medium or format, as long as you give appropriate credit to the original author(s) and the source, provide a link to the Creative Commons licence, and indicate if changes were made. The images or other third party material in this article are included in the article's Creative Commons licence, unless indicated otherwise in a credit line to the material. If material is not included in the article's Creative Commons licence and your intended use is not permitted by statutory regulation or exceeds the permitted use, you will need to obtain permission directly from the copyright holder. To view a copy of this licence, visit http://creativeco mmons.org/licenses/by/4.0/. The Creative Commons Public Domain Dedication waiver (http://creativecommons.org/publicdomain/ zero/1.0/) applies to the data made available in this article, unless otherwise stated in a credit line to the data. 


\section{Materials and methods \\ Tissue samples}

All human tissues were obtained from the Department of Gynaecology and Obstetrics, Qilu Hospital of Shandong University and Department of Gynaecology and Obstetrics, Jinan Women and Children Health Hospital after confirmation by a pathologist. Tissues were obtained with the patients' written and informed consent approved by the institution's Institutional Review Board of Qilu Hospital of Shandong University and Department of Gynaecology and Obstetrics.

\section{Immunohistochemistry}

Samples were fixed in $10 \%$ neutral buffered formalin for 7 days, embedded in paraffin and sectioned. Slides were baked, deparaffinization, blocked and incubated with anti-MAP7 (1:100 dilution, CST) overnight at $4{ }^{\circ} \mathrm{C}$. After washing, the samples were treated with corresponding secondary antibody, Colour was developed using a DAB (3,3'-diaminobenzidine) Horseradish Peroxidase Color Development Kit (Beytime).

\section{Cell culture}

The normal cervical epithelial ECT cell line and the human CC cell lines were obtained from American Type Culture Collection (Manassas, VA, USA). SiHa HeLa229 and MS751 cells were cultured in DMEM (Sigma-Aldrich, St. Louis, MO, USA) with $10 \%$ foetal bovine serum (FBS; Invitrogen, Carlsbad, CA, USA) and penicillin-streptomycin, whereas other cell lines were cultured in DMEM F-12 medium containing 10\% FBS with $1 \%$ penicillin-streptomycin.

\section{Real-time (RT) qPCR}

Total RNA from cells or tissues was extracted using TRIzol reagent (Thermo Fisher Scientific, Waltham, MA, USA) according to the manufacturer's protocol. Quantitative RT (qRT)-PCR was conducted using SYBR Green PCR Master Mix (Takara Bio) according to the protocol. The quantification was applied on a CFX96 Real-Time PCR Detection System (Bio-Rad, Hercules, CA, USA). Relative expression was normalized to Actin.

\section{Western blot assay}

Equal amounts of protein extracts were run on $12 \%$ SDS-PAGE and after trans-membrane and blocking, it was incubated with a primary antibody overnight at $4{ }^{\circ} \mathrm{C}$. Finally, the membrane was incubated with its respective horseradish peroxidase-conjugated secondary antibodies for $1 \mathrm{~h}$ at room temperature.
The protein bands of interest were visualized using enhanced chemiluminescence reagents (Millipore, Burlington, MA, USA).

\section{Trans-well assay}

Trans-well assay was applied to measure the migration and invasion ability. Certain number of $7 \times 10^{4}$ cells/well were resuspended in $250 \mu \mathrm{L}$ of plain medium without any FBS in the upper chamber $(8-\mu \mathrm{m}$ pore size, Costar, Corning, NY, USA) and the lower chamber was filled with $0.75 \mathrm{~mL}$ of medium supplemented with $10 \%$ FBS. After incubation for $24 \mathrm{~h}$ at $37{ }^{\circ} \mathrm{C}$, the invasive and migrated cells were fixed with $100 \%$ methanol and stained with $0.5 \%$ crystal violet for $20 \mathrm{~min}$ before counting under an inverted microscope.

\section{Wound healing assay}

We performed a wound healing assay to detect the migration ability of cells. We seeded $1 \times 105$ cells per well into a 6-well plate. Cells were incubated with complete medium (10\% FBS and 1\% PS with corresponding medium mentioned above). After the cells reached 100\% confluency, equal wounds were made with the $1 \mathrm{ml}$-pipette. After incubating for $24 \mathrm{~h}$. The relative width was measured by the ration of area and length. The area was calculated through ImageJ following the protocol automatically.

\section{Lentiviral production and stable cell line construction}

Lentiviral vectors expressing shRNA and MAP7 were obtained from Bio-Chemistry China. CC cells were then transduced by the above lentiviruses with polybrene (8 $\mathrm{mg} / \mathrm{ml}$, Sigma). After incubating for $24 \mathrm{~h}$, cells were selected with $2 \mathrm{mg} / \mathrm{ml}$ puromycin for 3 days. Stable cell lines were harvested.

\section{Statistical analysis}

Statistical analyses were performed using SPSS version 18.0 (SPSS Inc., Chicago, IL, USA). Data are presented as the mean $\pm \mathrm{SD}$. The Chi squared test was used to analyse clinicopathological characteristics. Comparisons between two groups were evaluated using Student's $t$ test. Differences among the groups were tested using a oneway ANOVA followed by Turkey post test. All experiments were repeated at least three times. A p value $<0.05$ was considered statistically significant.

\section{Results}

MAP7 was upregulated in cervical cancer

We scanned the most authoritative database in cancerTCGA database and identified MAP7 was upregulated in 306 Cervical cancer compared with normal tissue (Fig. 1a). The number of normal tissues in TCGA database was small so we detected the mRNA level of MAP7 


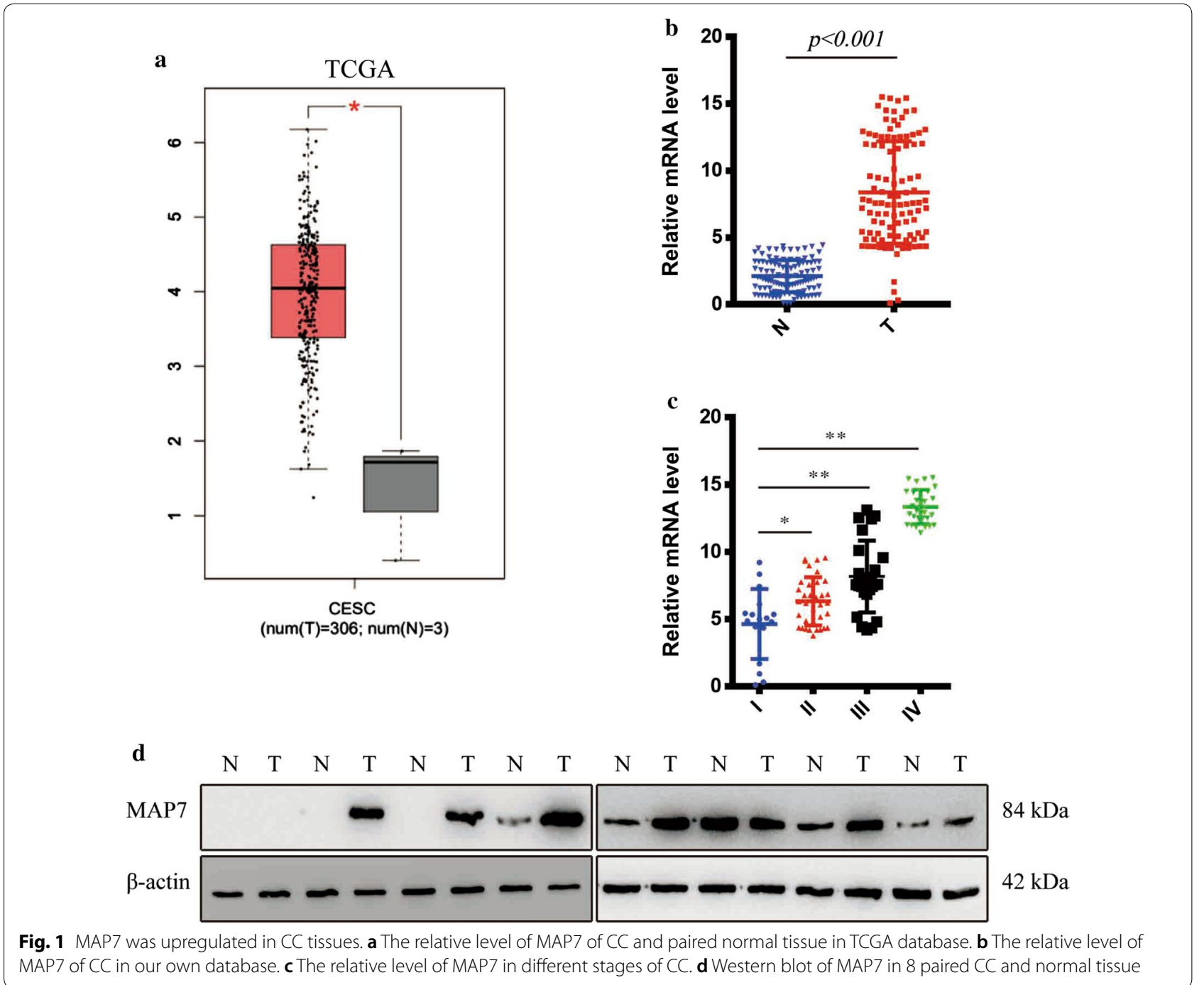

Table 1 The clinical characteristic of patients in our own database

\begin{tabular}{|c|c|c|c|c|}
\hline Characteristics & $\begin{array}{l}\text { Patients } \\
(n=105)\end{array}$ & $\begin{array}{l}\text { MAP7 lower } \\
(n=31)\end{array}$ & $\begin{array}{l}\text { MAP7 } \\
\text { higher } \\
(n=74)\end{array}$ & $p$ value \\
\hline \multicolumn{5}{|l|}{ Age (years) } \\
\hline$<55$ & 51 & 38 & 13 & $>0.05$ \\
\hline$\geq 55$ & 54 & 36 & 18 & \\
\hline \multicolumn{5}{|l|}{ Stage } \\
\hline$I+\|$ & 42 & 24 & 18 & $<0.01$ \\
\hline$I I I+I V$ & 63 & 7 & 56 & \\
\hline \multicolumn{5}{|l|}{ Size (cm) } \\
\hline$<4$ & 43 & 16 & 27 & $<0.01$ \\
\hline$\geq 4$ & 62 & 15 & 47 & \\
\hline \multicolumn{5}{|l|}{ Lymph node } \\
\hline Negative & 54 & 20 & 34 & $<0.01$ \\
\hline Positive & 51 & 11 & 40 & \\
\hline
\end{tabular}

in $105 \mathrm{CC}$ tissues and paired normal tissues mRNA level of MAP7 was upregulated in CC tissue $(\mathrm{p}<0.001)$ (Fig. 1b). The clinical features of the 105 patients was shown in Table 1. We next analysed the correlation of MAP7 and the clinical stage of Cervical cancer, we next divided the whole cohort into 4 groups according to the clinical stage. the level of MAP7 was correlated with the clinical stage. The mRNA level of MAP7 was highest in stage IV while the mRNA level of MAP7 in stage I was the lowest (Fig. 1c). We next detected the protein level of MAP7 in 8 patients. The protein level of MAP7 increased in 6 out of 8 patients (Fig. 1d).

\section{MAP7 was correlate with the prognosis}

We applied IHC and performed the survival analysis according to the expression of MAP7(Fig. 2a). MAP7 was corelated with the overall survival time (OS) and 


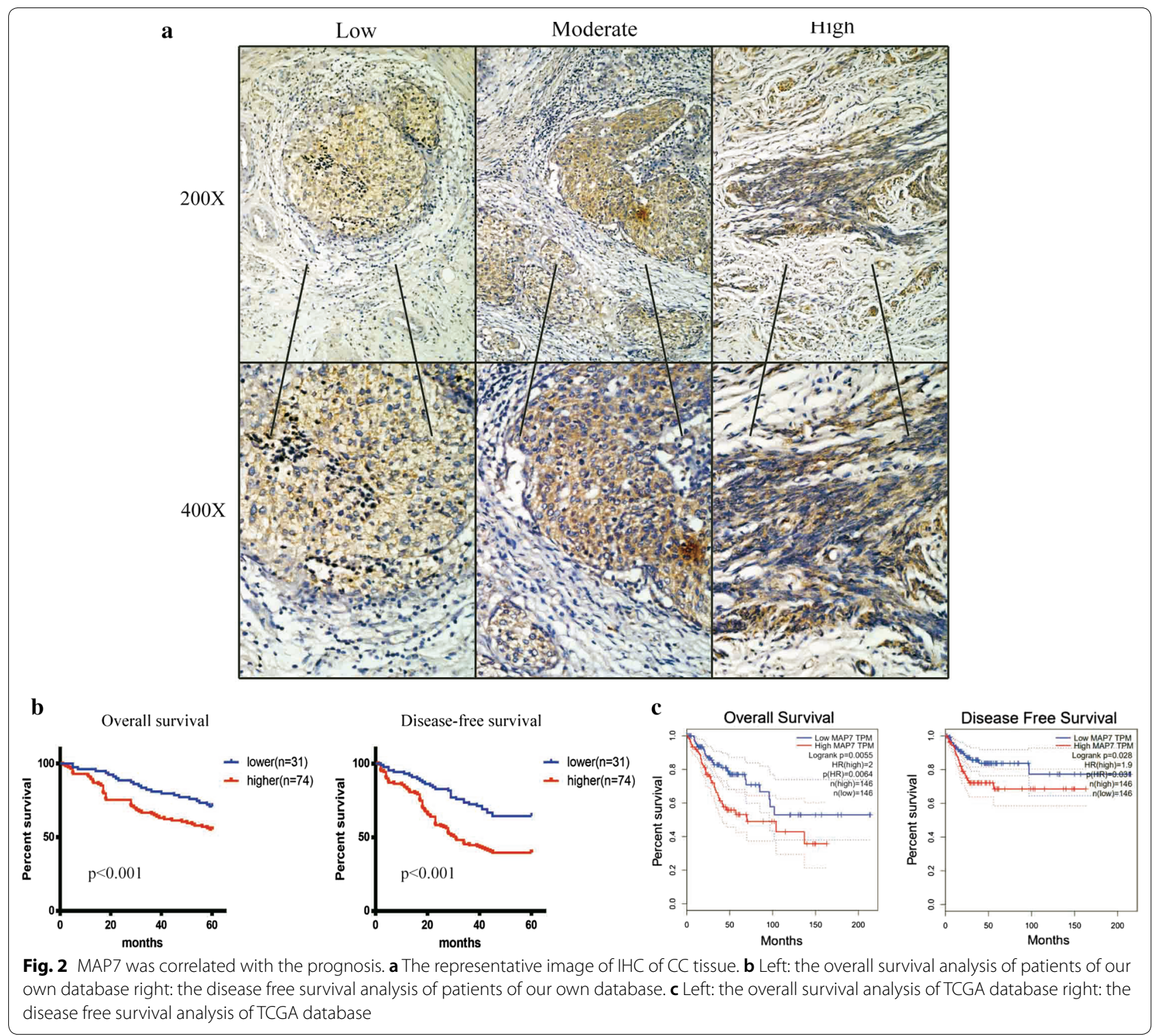

disease-free survival time (DFS). Patients with higher level of MAP7 has shorter OS and DFS in our own database (Fig. 2b). We next scanned the TCGA database and found that MAP7 was upregulated in tumour and negative correlated with OS and DFS (Fig. 2c).

\section{Stable cell line establishment}

To uncover the biological function of MAP7, we detect the mRNA level of MAP7 in cervical cancer cell lines. MAP7 was upregulated in CC cell line. HeLa and SiHa possessed the higher level of MAP7 while C33A and MS751 possessed the lowest level of MAP7 (Fig. 3a). We next establish stable cell line with lentivirus. The mRNA and protein level of MAP7 was shown in Fig. 3b, c.

\section{MAP7 promotes the migration and invasion of $\mathrm{CC}$ cell}

MAP7 was shown to be negatively correlated with prognosis as previously described. However, the potential function was still unknown, to uncover the biological function of MAP7 on CC cells, we next examined the function of MAP7 on migration and invasion as recurrence and metastasis were the most reasons for patient-death. We applied the wound healing assay, the Trans-well assay and the invasion chamber assay to measure the migrate ability. The wound healed more rapidly in the MAP7-overexpressing cell line than in the MAP7 knockdown cell line (Fig. 4a, b), the MAP7-overexpressing cells harbour improved migrate 


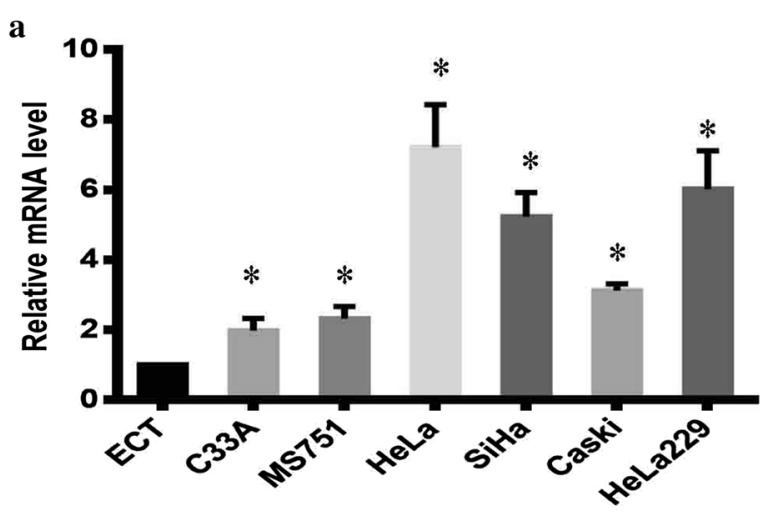

b

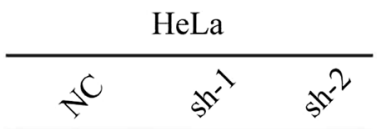

MAP7

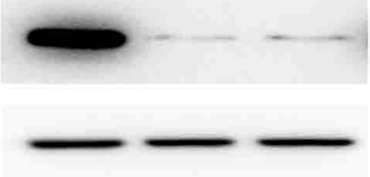

$84 \mathrm{kDa}$

$\beta$-actin

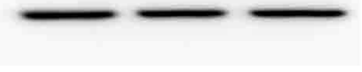

$42 \mathrm{kDa}$

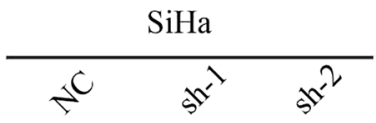

MAP7

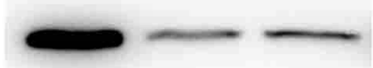

$84 \mathrm{kDa}$

$\beta$-actin

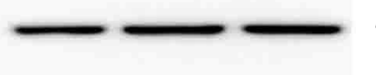

$42 \mathrm{kDa}$
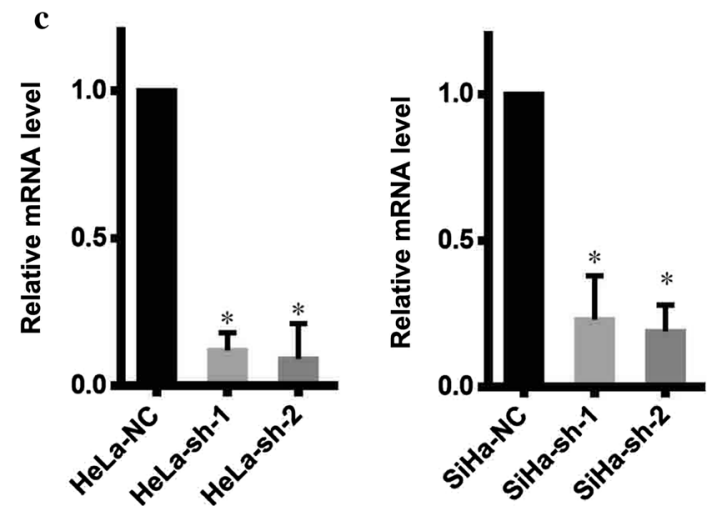
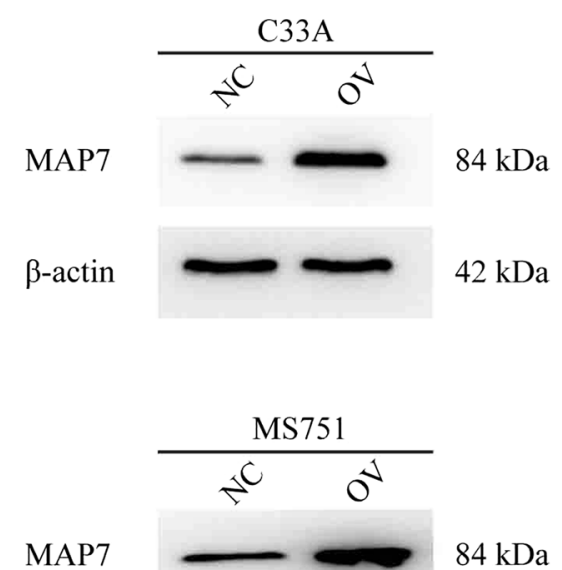

$84 \mathrm{kDa}$

MAP7

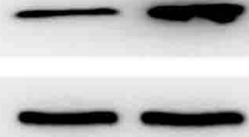

$42 \mathrm{kDa}$

Fig. 3 Stable cell line was established. a The relative mRNA level of MAP7 in different cell lines. b Western blot of MAP7 of different cell lines. $\mathbf{c}$ The relative mRNA level of MAP7 of different cell lines

ability than the MAP7 knockdown cells in the Transwell assay (Fig. 4c, d) as well as the invasion chamber assay (Fig. 4e, f). Taken above data, MAP7 promotes the migration and invasion of CC.

\section{MAP7 promotes the EMT of CC}

We have proved that MAP7 promotes migration and invasion in CC. EMT markers are the most common markers reflecting cell mesenchymal and epithelial status. We detected the expression pattern of classic EMT 

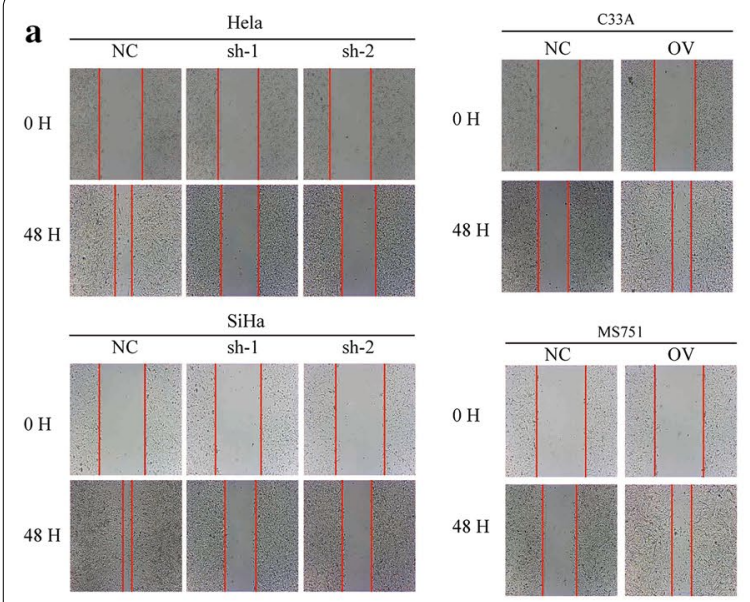

b
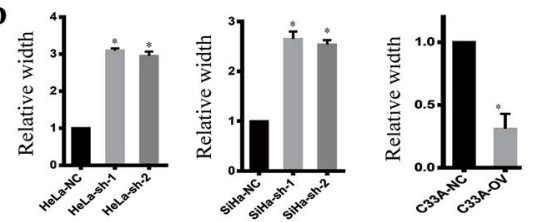

c
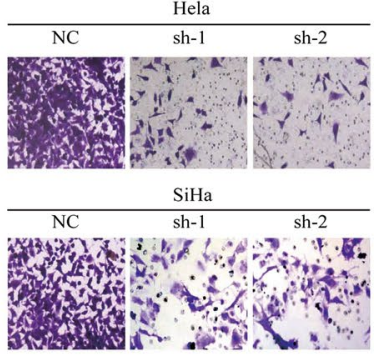

Hela
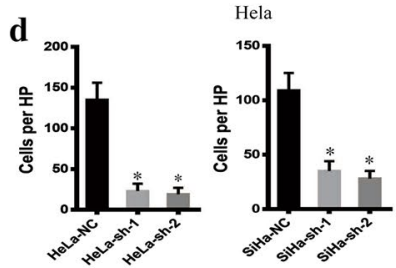

e
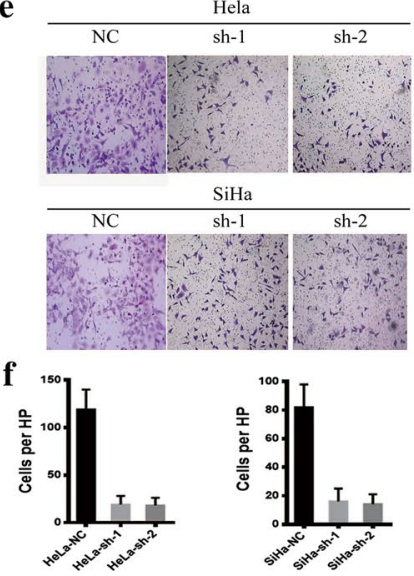

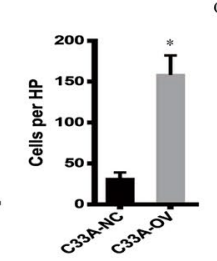

C3)A
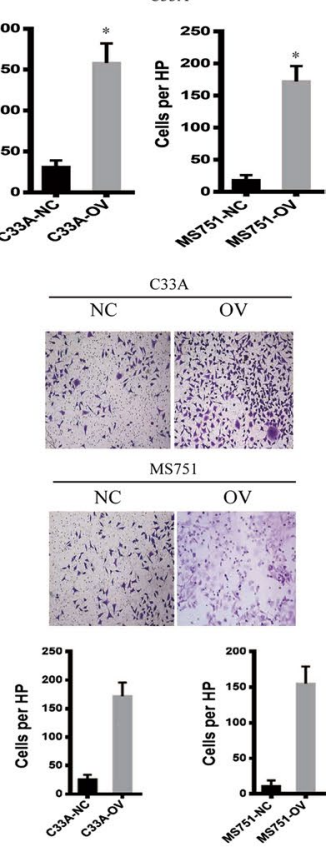

Fig. 4 Map7 promotes the migration and invasion of CC. a The representative image of wounding healing. $\mathbf{b}$ The statistical analysis of wound healing. c The representative image of trans-well. $\mathbf{d}$ The statistical analysis of trans-well. e The representative image of invasion chamber. $\mathbf{f}$ The statistical analysis of invasion chamber

markers. Mesenchymal markers such as N-cadherin, Snail and Vimentin decreased in MAP7 knocking down cells, but epithelial markers such as E-cadherin increased in the shMAP7 cell line; however, mesenchymal markers increased but epithelial markers decreased at both the RNA and protein level in the MAP7-overexpressing cell line (Fig. 5), which coordinates with the former results.

\section{MAP7 promotes the cell cycle through modulating the autophagy}

We have proved that MAPT promotes the migration and invasion in CC through EMT pathway. MAP7 was reported to involve in the autophagy pathway. We next detect the cell cycle check point and the autophagy pathway. The results showed that the MAP7 knocking down resulted in the disturbed cell cycle. The expression level of cell cycle check point decreased in cells with lower level of MAP7 (Fig. 6a). As presented in Fig. 6b, the ratio of LC3B-II/LC-3BI increased with the knocking down of MAP7 and p62 showed the opposite change which indicates that MAP7 modulates the autophagy pathway.

\section{Discussion}

Human cervical cancer was one of the most common malignancy worldwide. Though advancement in radio therapy and immunotherapy, patients with late stage of cervical cancer still suffers from recurrence and metastasis. Therefore, more biomarkers and therapeutic targets were needed.

Microtubule formation was crucial for the mitosis, Microtubules are continually remodeled through alternating growth and shrinkage of their extremities, known as dynamic instability $[5,9]$. Microtubule associated protein 7 (MAP7) was crucial in the regulating of microtubule bundling and dynamics. Researches has shown that MAP7 plays a novel role in the formation of microtubule in neuron through directly binding to the microtubule and promotes its' stabilization [10]. Further domain analysis of MAP7 shows that MAP7 enhances kinesin-1 recruitment to microtubules, both $\mathrm{N}$ and $\mathrm{P}$ domains are responsible for branch formation, whereas the C-terminal kinesin-interacting domain is 


\begin{tabular}{|c|c|c|c|c|c|}
\hline & Hela & $\mathrm{SiHa}$ & $\mathrm{C} 33 \mathrm{~A}$ & MS751 & \\
\hline & $\overbrace{}^{c} \mathrm{sc}^{2} \mathrm{~s}^{2}$ & $\varepsilon^{c} x^{\prime} s^{2}$ & $\therefore 0$ & $\therefore 0$ & \\
\hline $\mathrm{N}$-cad & $0-\cdots$ & $\infty$ & $\longrightarrow-$ & $=-$ & $140 \mathrm{kDa}$ \\
\hline Vimentin & 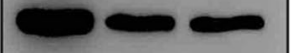 & --- & $-\longrightarrow$ & - & $57 \mathrm{kDa}$ \\
\hline Snail & $-\cdots \cdots$ & -- & - & $\longrightarrow$ & $29 \mathrm{kDa}$ \\
\hline E-cad & $-\infty$ & -- & -- & - & $135 \mathrm{kDa}$ \\
\hline$\beta$-actin & $-\infty$ & $-\infty$ & $\longrightarrow$ & - & $42 \mathrm{kDa}$ \\
\hline
\end{tabular}

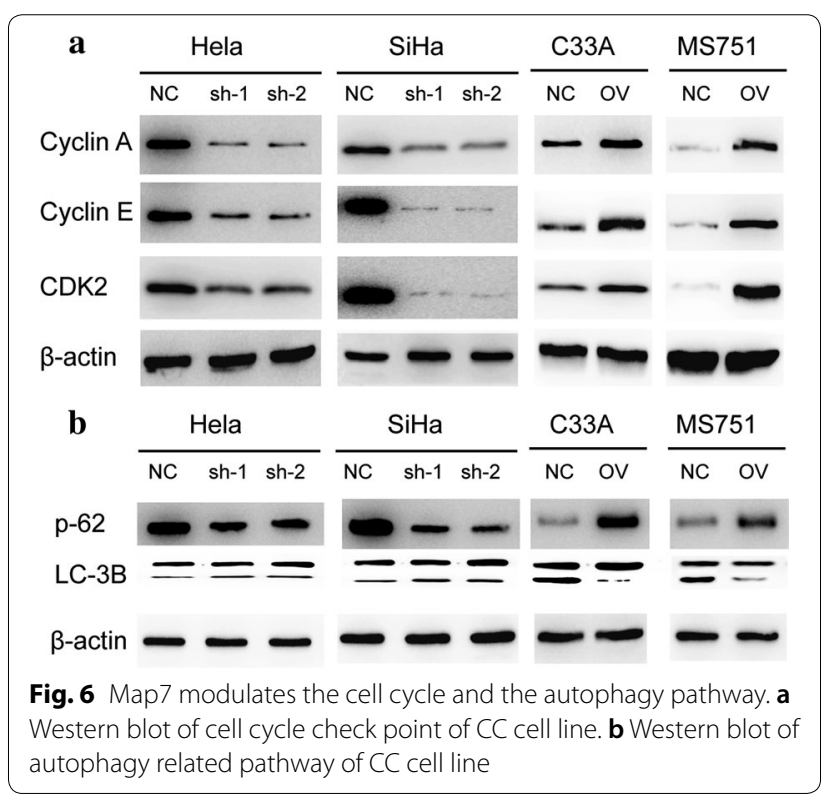

important for promoting axon and branch growth and branch growth mediated by the $\mathrm{C}$ domain can compete for main axon growth [6]. As the domain of MAP7 exert its' function independence of full length of MAP7, proteins with the same domain of MAP7 was reported to involve into the formation of microtubule [11]. MAP7 was reported to contribute to the self-renewal of stem cells [12]. However, the role of MAP7 in cancers was rarely studied. Studies showed that MAP7 was upregulated in young patients with cytogenetically normal acute myeloid leukemia and predicts poor outcome [13]. The potential function and mechanism of MAP7 in cancer was still unknown. Hence, we examine the level of MAP7 in cervical cancer and its' correlation with prognosis. Patients with higher level of MAP7 harbor shorter overall survival time and disease free time. To uncover the biological function of MAP7, we detect the mRNA and protein level of MAP7 in CC cell line and establish knockdown and overexpress cell lines. Cells with higher level of MAP7 migrates and invades more easily than cells with lower level of MAP7. We next detect the mesenchymal markers and epithelial markers in the cells above. MAP7 promotes the transition from epithelial status to mesenchymal status. We next detect the autophagy associated pathway. The results showed that the ratio of LC3B-II/LC-3BI increased with the knocking down of MAP7 and p62 showed the opposite change which indicates that MAP7 modulates the autophagy pathway.

Taken together, our research shows that MAP7 promotes migration and invasion and progression of human cervical cancer through modulating the autophagy pathway. Further specific mechanism MAP7 on cancer cell was still needed to make it an ideal therapeutic target.

\section{Conclusion}

The findings of this study demonstrate that MAP7 is overexpressed in CC tissues is strongly associated with a poor prognosis. MAP7 promotes migration and invasion and progression of human cervical cancer through modulating the autophagy pathway. Therefore, MAP7 can serve as the potential therapeutic target.

\section{Acknowledgements}

We thank Professor Wang for technical assistance.

\section{Authors' contributions}

$\mathrm{HZ}$ and $\mathrm{CC}$ designed the research; all the authors were engaged into the performance of the research data analysis and wrote the literal editing. All authors read and approved the final manuscript. 


\section{Funding}

No funding was received.

\section{Availability of data and materials}

All the datasets supporting the conclusions of this article are included within the article.

\section{Ethics approval and consent to participate}

This study was approved by the Medical Ethics and Human Clinical Trial Committee, and Animal Use and Management Committee at Firs Jinan Women and Children Health Hospital.

\section{Consent for publication}

Consent for publication and Animal Use and Management Committee at Qilu Hospital of Shandong University. All authors agreed to publish the article in the journal.

\section{Competing interests}

The authors declare that they have no competing interests.

\section{Author details}

1 Department of Gynaecology and Obstetrics, Jinan Women and Children Health Hospital, No. 2 Jianguo Xiaojing 3rd Road Center Area, Jinan, Shandong 250001, China. ${ }^{2}$ Department of Pain, Qilu Hospital of Shandong University, Jinan, China. ${ }^{3}$ Department of Anethesia, Jinan Women and Children Health Hospital, No. 2 Jianguo Xiaojing 3rd Road Center Area, Jinan, Shandong 250001, China.

Received: 15 October 2019 Accepted: 2 January 2020 Published online: 13 January 2020

\section{References}

1. Shaitelman SF, Cromwell KD, Rasmussen JC, Stout NL, Armer JM, Lasinski $\mathrm{BB}$, Cormier JN. Recent progress in the treatment and prevention of cancer-related lymphedema. CA Cancer J Clin. 2015;65(1):55-81.

2. Maresso KC, Tsai KY, Brown PH, Szabo E, Lippman S, Hawk ET. Molecular cancer prevention: current status and future directions. CA Cancer I Clin. 2015;65(5):345-83.

3. Porcza LM, Simms C, Chopra M. Honey and cancer: current status and future directions. Diseases. 2016:4(4):30.
4. Du L, Risinger AL, Yee SS, Ola AR, Zammiello CL, Cichewicz RH, Mooberry SL. Identification of C- 6 as a new site for linker conjugation to the taccalonolide microtubule stabilizers. J Nat Prod. 2019;82(3):583-8.

5. Camargo OG, Falk S, Johansson PA, Peyre E, Broix L, Sahu SK, Hirst W, Schlichthaerle T, De Juan RC, Draganova K, Vinopal S, Chinnappa K, Gavranovic A, Karakaya T, Steininger T, Merl-Pham J, et al. The centrosome protein AKNA regulates neurogenesis via microtubule organization. Nature. 2019;567(7746):113.

6. Tymanskyj SR, Yang BH, Verhey KJ, Ma L. MAP7 regulates axon morphogenesis by recruiting kinesin-1 to microtubules and modulating organelle transport. ELIFE. 2018;22(7):e36374.

7. Blum C, Graham A, Yousefzadeh M, Shrout J, Benjamin K, Krishna M, Hoda R, Hoda R, Cole DJ, Garrett-Mayer E, Reed C, Wallace M, Mitas M. The expression ratio of Map7/B2M is prognostic for survival in patients with stage II colon cancer. Int J Oncol. 2008;33(3):579-84.

8. Yan X, Liang H, Deng T, Zhu K, Zhang S, Wang N, Jiang X, Wang X, Liu R, Zen K, Zhang CY, Ba Y, Chen X. The identification of novel targets of miR16 and characterization of their biological functions in cancer cells. Mol Cancer. 2013;12:92.

9. Yadav SK, Stojkov D, Feigelson SW, Roncato F, Simon HU, Yousefi S, Alon R Chemokine-triggered microtubule polymerization promotes neutrophil chemotaxis and invasion but not transendothelial migration. J Leukoc Biol. 2019;105(4):755-66.

10. Tymanskyj SR, Yang B, Falnikar A, Lepore AC, Ma L. MAP7 regulates axon collateral branch development in dorsal root ganglion neurons. J Neurosci. 2017;37(6):1648-61.

11. Yadav S, Verma PJ, Panda D. C-terminal region of MAP7 domain containing protein 3 (MAP7D3) promotes microtubule polymerization by binding at the C-terminal tail of tubulin. PLoS ONE. 2014;9(6):e99539.

12. Gallaud E, Caous R, Pascal A, Bazile F, Gagne JP, Huet S, Poirier GG, Chretien D, Richard-Parpaillon L, Giet R. Ensconsin/Map7 promotes microtubule growth and centrosome separation in Drosophila neural stem cells. J Cell Biol. 2014;204(7):1111-21.

13. Fu L, Fu H, Zhou L, Xu K, Pang Y, Hu K, Wang J, Tian L, Liu Y, Wang J, Jing H, Huang W, Ke X, Shi J. High expression of MAP7 predicts adverse prognosis in young patients with cytogenetically normal acute myeloid leukemia. Sci Rep. 2016;6:34546.

\section{Publisher's Note}

Springer Nature remains neutral with regard to jurisdictional claims in published maps and institutional affiliations.
Ready to submit your research? Choose BMC and benefit from:

- fast, convenient online submission

- thorough peer review by experienced researchers in your field

- rapid publication on acceptance

- support for research data, including large and complex data types

- gold Open Access which fosters wider collaboration and increased citations

- maximum visibility for your research: over 100M website views per year

At BMC, research is always in progress.

Learn more biomedcentral.com/submissions 